\title{
In vitro micropropagation of water hyacinth (Eichhornia crassipes)
}

\author{
Eun-Jung Suh · Byoung Mo Park · Bong Hee Han
}

Received: 10 September 2010 / Accepted: 24 September 2010

(C) Korean Society for Plant Biotechnology

\begin{abstract}
This study was conducted to refine a micropropagation method of water hyacinth (Eichhornia crassipes) in vitro. When young shoots were cultured on media with various concentrations of $\mathrm{BA}$ or TDZ alone, LS medium containing $5.0 \mathrm{mgl}^{-1} \mathrm{BA}$ was found favorable for shoot proliferation from young shoots with a mean of 4.2 shoots. Using BA together with IAA, more shoots were obtained on LS medium containing $5.0 \mathrm{mgl}^{-1} \mathrm{BA}$ and $1.0 \mathrm{mgl}^{-1}$ IAA with a mean of 5.7 shoots. In liquid medium, number of shoots and fresh weight per explant increased significantly. The best shoot proliferation and increasing of fresh weight were achieved on LS liquid medium containing $5.0 \mathrm{mgl}^{-1} \mathrm{BA}$ and $1.0 \mathrm{mgl}^{-1}$ IAA with 6.9 shoots and more than $4,000 \mathrm{mg}$ fresh weight. Of the different concentrations of LS salt, double strength of LS medium provided the highest shoot proliferation with 7.3 shoots, and fresh weight with 5,539 mg per explant. Shoot proliferation on LS medium containing $50 \mathrm{gl}^{-1}$ sucrose had better results with 8.7 shoots and $5,979 \mathrm{mg}$ per explant in fresh weight than other conditions. In conclusion, the optimal level for shoot proliferation and biomass increase of water hyacinth was attained with the application of the double strength of LS medium containing $5.0 \mathrm{mgl}^{-1} \mathrm{BA}$, $1.0 \mathrm{mgl}^{-1}$ IAA and $50 \mathrm{gl}^{-1}$ sucrose.
\end{abstract}

Keywords water hyacinth, LS medium, shoot proliferation, Eichhornia crassipes

\footnotetext{
E. J. Suh

Department of Bio-crop Development Division, National Academy of Agricultural Science, RDA, 441-857, Korea

B. M. Park

Department of Environment Landscape Architecture Design, College of Environmental Bioresource Sciences, Chonbuk National University, Iksan 570-752, Korea

B. H. Han $(\bowtie)$

Department of Seed Service, Foundation of Agri. Tech. Commercialization \& Transfer, 441-100, Korea

e-mail: bhhan@efact.or.kr
}

\section{Introduction}

Water hyacinth is native to Brazil of South America, and is regarded as an invasive weed plants because of its vigorous ability of propagation by stolon and seeds. It is also known as the most representative and a fast-growing aquatic macrophyte for water purification, and has been used to remove heavy metals in contaminated water (Mishima et al. 2006; Wu et al. 2008). Nutrient removal from wastewater has become an important issue due to the problems of eutrophication in many areas of the world. The removal of nutrients from contaminated water by conventional sewage treatment plants is not an economical solution. A promising, cost-effective and environmentally acceptable solution is phytoremediation, which applies aquatic macrophytes for water purification (Mishima et al. 2006). The ability of aquatic macrophytes to uptake nutrients directly from contaminated water and to assimilate them into their body with their growth (Reddy and DeBusk 1985) is the greatest benefit of phytoremediation. Additionally, other abilities such as assimilation of heavy metals (Keskinkan et al. 2003), and removal and degradation of persistent organic pollutants from contaminated water (Roy and Hanninen 1994) make aquatic macrophyte purification systems more attractive. Recently, the biomass composition of water hyacinth was identified with low lignin and high cellulose, and can also be a potential feedstock for biofuel production (Bhattacharya et al. 2010). Moreover, water hyacinth can be considered as ornamental plant since it provides beautiful blue to lilac colored flowers. With the increasing popularity of indoor gardening in Korea, water hyacinth is sold in many ornamental plant shops for its attractive and unusual architecture. In spite of much demand in spring, the supply cannot meet demand because it hardly survives during winter (below $12{ }^{\circ} \mathrm{C}$ ) (Gao and Li 2006).

Because of this limitation, the cultivation and propagation of water hyacinth during winter are done in special 
environmental conditions like greenhouse or culture room. Therefore, a method of micropropagation by in vitro culture is required to rapidly propagate water hyacinth to provide enough supply in spring. This study was conducted to establish the micropropagation protocol in vitro of water hyacinth.

\section{Materials and methods}

Plant material and surface sterilization

Water hyacinth (E. crassipes) was purchased from commercial seed company (Dalimseed, Korea) and planted in sterilized soil. When leaves opened, stolons was removed and sterilized with $70 \%$ ethyl alcohol for $30 \mathrm{sec}$ and $1.0 \%$ sodium hypochlorite $(\mathrm{NaOCl})$ for $15 \mathrm{~min}$. After three times of rinsing with sterile distilled water, the explants were inoculated on LS culture medium (Linsmaire and Skoog 1965) containing 3.0 $\mathrm{mgl}^{-1}$ BA and $0.5 \mathrm{mg} \mathrm{l}^{-1}$ IAA.

\section{Media preparation and shoot proliferation}

Shoots (five per culture vessel) were inoculated in 400 $\mathrm{mL}$ of glass bottles (Samgkwang, Korea) containing $80 \mathrm{~mL}$ LS medium. It was supplemented by either benzyl adenine (BA; 0.5, 1.0, 2.0, 3.0, $5.0 \mathrm{mgl}^{-1}$ ) or thidiazuron (TDZ; $0.05,0.1,0.2,0.3,0.5 \mathrm{mgl}^{-1}$ ) for faster shoot multiplication. BA $\left(2.0,3.0,5.0 \mathrm{mgl}^{-1}\right)$ was added in LS medium in combination with IAA $\left(0.1,0.5,1.0 \mathrm{mgl}^{-1}\right)$ to increase shoot production. Plant agar $\left(8 \mathrm{gl}^{-1}\right.$, Duchefa, The Netherlands), gelrite ( $\mathrm{gl}^{-1}$, Duchefa, The Netherlands) and liquid culture were used as medium to compare plant response by gelling substrates. The experiments on concentrations of LS salt $(1 / 2,1,2 x)$ and sucrose $\left(30,50,70,90 \mathrm{gl}^{-1}\right)$ were also conducted to select the suitable concentration for shoot proliferation. The $\mathrm{pH}$ was adjusted at 5.8 before the culture media were autoclaved at $121^{\circ} \mathrm{C}$ for $15 \mathrm{~min}$.

Culture conditions and data analysis

Every experimental set-up has four replications in four bottles with five explants per bottle. All cultures were incubated in a growth room maintained at $25 \pm 2^{\circ} \mathrm{C}$. The cultures were illuminated at $40 \mu \mathrm{mol} . \mathrm{m}^{-2} . \mathrm{s}^{-1} \mathrm{PPFD}$ (Photosynthetic Photon Flux Density; fluorescent lamps) and $16 \mathrm{~h} . \mathrm{d}^{-1}$ photoperiod. Data were recorded after 4 weeks in culture on shoot proliferation. The statistical analysis comparing the various treatments in all experiments was performed using Duncan's multiple range test (DMRT; Duncan 1955).

\section{Results and discussion}

Young shoots were cultured on LS media supplemented with various concentrations of BA or TDZ. Shoot proliferation was very favorable on LS media containing $5.0 \mathrm{mgl}^{-1}$ BA or $0.01 \sim 0.2 \mathrm{mgl}^{-1} \mathrm{TDZ}$ with more than 3.9 shoots. Shoot, root length, and number of roots were very low in some treatments compared to other treatments. However, fresh weight per explant was high on LS media containing 2.0 5.0 mgl ${ }^{-1}$ BA. Considering the number of shoots and fresh weight, LS medium containing

Table 1 Effects of BA and $\mathrm{TDZ}^{\mathrm{Z}}$ on shoot proliferation and growth from shoots of water hyacinth after 4 weeks in culture

\begin{tabular}{|c|c|c|c|c|c|}
\hline $\begin{array}{l}\text { Cytokinin } \\
\left(\mathrm{mgl}^{-1}\right)\end{array}$ & $\begin{array}{l}\text { No. of shoots } \\
\text { /explant }\end{array}$ & $\begin{array}{l}\text { Shoot length } \\
(\mathrm{cm})\end{array}$ & $\begin{array}{l}\text { No. of roots } \\
\text { /explant }\end{array}$ & $\begin{array}{l}\text { Root length } \\
\quad(\mathrm{cm})\end{array}$ & $\begin{array}{l}\text { FW (mg) } \\
\text { /explant }\end{array}$ \\
\hline Control & $1.0 \mathrm{e}^{\mathrm{y}}$ & $6.1 \mathrm{a}$ & $20.3 \mathrm{a}$ & $9.1 \mathrm{a}$ & $3,120 \mathrm{a}$ \\
\hline BA 0.5 & $1.6 \mathrm{ce}$ & $4.1 \mathrm{~b}$ & $15.7 \mathrm{~b}$ & $4.7 \mathrm{~b}$ & $2,177 \mathrm{ab}$ \\
\hline 1.0 & $2.1 \mathrm{~cd}$ & $3.2 \mathrm{c}$ & $10.9 \mathrm{c}$ & $3.9 \mathrm{bc}$ & $1,903 \mathrm{~b}$ \\
\hline 2.0 & $2.7 \mathrm{bcd}$ & $2.5 \mathrm{~cd}$ & $7.7 \mathrm{~cd}$ & $2.6 \mathrm{~cd}$ & $2,323 \mathrm{ab}$ \\
\hline 3.0 & $3.1 \mathrm{abc}$ & $2.6 \mathrm{~cd}$ & $7.5 \mathrm{~cd}$ & $2.8 \mathrm{~cd}$ & $2,380 \mathrm{ab}$ \\
\hline 5.0 & $4.2 \mathrm{a}$ & $2.4 \mathrm{~d}$ & $4.9 \mathrm{~d}$ & $1.6 \mathrm{de}$ & $2,157 \mathrm{ab}$ \\
\hline TDZ 0.01 & $4.2 \mathrm{a}$ & $2.0 \mathrm{~d}$ & $5.1 \mathrm{~d}$ & $1.4 \mathrm{de}$ & $1,975 \mathrm{~b}$ \\
\hline 0.1 & $4.0 \mathrm{a}$ & $2.3 \mathrm{~d}$ & $5.9 \mathrm{~d}$ & $1.5 \mathrm{de}$ & $2,023 \mathrm{~b}$ \\
\hline 0.2 & $3.9 \mathrm{a}$ & $1.9 \mathrm{~d}$ & $6.3 \mathrm{~cd}$ & $1.2 \mathrm{e}$ & $1,940 \mathrm{~b}$ \\
\hline 0.5 & $3.7 \mathrm{ab}$ & $2.2 \mathrm{~d}$ & $9.5 \mathrm{~cd}$ & $1.4 \mathrm{de}$ & $1,948 \mathrm{~b}$ \\
\hline
\end{tabular}

\footnotetext{
${ }^{\mathrm{z}}$ thidiazuron

${ }^{y}$ Duncan's multiple range test $(P \leq 0.05)$
} 
Table 2 Combined effects of BA and IAA on shoot proliferation and growth from shoots of water hyacinth after 4 weeks in culture

\begin{tabular}{|c|c|c|c|c|c|}
\hline $\begin{array}{l}\text { Cytokinin } \\
\left(\mathrm{mgl}^{-1}\right)\end{array}$ & $\begin{array}{l}\text { No. of shoots } \\
\text { /explant }\end{array}$ & $\begin{array}{l}\text { Shoot length } \\
(\mathrm{cm})\end{array}$ & $\begin{array}{l}\text { No. of roots } \\
\text { /explant }\end{array}$ & $\begin{array}{l}\text { Root length } \\
\text { (cm) }\end{array}$ & $\begin{array}{c}\text { FW (mg) } \\
\text { /explant }\end{array}$ \\
\hline Control & $1.1 \mathrm{e}^{\mathrm{z}}$ & $5.2 \mathrm{a}$ & $19.5 \mathrm{a}$ & $6.7 \mathrm{a}$ & $3,366 \mathrm{ab}$ \\
\hline \multirow{3}{*}{$\begin{array}{r}\text { BA } 2.0+\text { IAA } 0 \\
0 \\
1\end{array}$} & $2.2 \mathrm{de}$ & $3.2 \mathrm{bc}$ & $17.3 \mathrm{ab}$ & $4.5 \mathrm{bc}$ & $2,719 \mathrm{~b}$ \\
\hline & $2.4 \mathrm{~d}$ & $3.3 \mathrm{bc}$ & $15.5 \mathrm{ab}$ & $3.6 \mathrm{~cd}$ & $2,765 \mathrm{~b}$ \\
\hline & $2.1 \mathrm{de}$ & $3.5 \mathrm{~b}$ & $18.7 \mathrm{a}$ & $5.0 \mathrm{~b}$ & $2,898 \mathrm{~b}$ \\
\hline \multirow{3}{*}{ BA $3.0+$ IAA } & $4.1 \mathrm{bc}$ & $2.8 \mathrm{c}$ & $13.7 \mathrm{bc}$ & $3.3 \mathrm{cde}$ & $2,157 \mathrm{ab}$ \\
\hline & $3.7 \mathrm{bc}$ & $2.7 \mathrm{c}$ & $10.5 \mathrm{~cd}$ & $2.0 \mathrm{e}$ & $3,196 \mathrm{ab}$ \\
\hline & $3.2 \mathrm{~cd}$ & $2.9 \mathrm{bc}$ & $11.6 \mathrm{~cd}$ & $3.0 \mathrm{de}$ & $3,539 \mathrm{ab}$ \\
\hline \multirow{3}{*}{$\begin{array}{r}0 \\
\text { BA } 5.0+\text { IAA } \\
0 \\
1\end{array}$} & $4.0 \mathrm{bc}$ & $3.1 \mathrm{bc}$ & $8.6 \mathrm{~d}$ & $2.8 \mathrm{de}$ & $2,839 \mathrm{~b}$ \\
\hline & $4.7 \mathrm{ab}$ & $3.0 \mathrm{bc}$ & $8.4 \mathrm{~d}$ & $2.7 \mathrm{de}$ & $3,071 \mathrm{ab}$ \\
\hline & $5.7 \mathrm{a}$ & $2.8 \mathrm{c}$ & $7.6 \mathrm{~d}$ & $2.0 \mathrm{e}$ & 3,862 a \\
\hline
\end{tabular}

${ }^{\mathrm{z}}$ Duncan's multiple range test $(P \leq 0.05)$

Table 3 Effects of gelling substances in medium ${ }^{\mathrm{z}}$ on shoot proliferation and growth of water hyacinth after 4 weeks in culture

\begin{tabular}{cccccc}
\hline $\begin{array}{c}\text { Gelling } \\
\text { substance }\end{array}$ & $\begin{array}{c}\text { No. of shoots } \\
\text { /explant }\end{array}$ & $\begin{array}{c}\text { Shoot length } \\
(\mathrm{cm})\end{array}$ & $\begin{array}{c}\text { No. of roots } \\
\text { /explant }\end{array}$ & $\begin{array}{c}\text { Root length } \\
(\mathrm{cm})\end{array}$ & $\begin{array}{c}\text { FW (mg) } \\
\text { /explant }\end{array}$ \\
\hline $\begin{array}{c}\text { Plant agar } \\
8 \mathrm{gl}^{-1}\end{array}$ & $4.2 \mathrm{~b}^{\mathrm{y}}$ & $2.7 \mathrm{a}$ & $10.3 \mathrm{a}$ & $2.6 \mathrm{a}$ & $2,208 \mathrm{~b}$ \\
$\begin{array}{c}\text { Gelite } \\
2 \mathrm{gl}^{-1}\end{array}$ & $4.4 \mathrm{~b}$ & $2.6 \mathrm{a}$ & $7.1 \mathrm{ab}$ & $1.1 \mathrm{~b}$ & $2,440 \mathrm{~b}$ \\
$\begin{array}{c}\text { Liquid } \\
\text { culture }\end{array}$ & $6.9 \mathrm{a}$ & $2.7 \mathrm{a}$ & $5.3 \mathrm{~b}$ & $0.6 \mathrm{~b}$ & $4,039 \mathrm{a}$ \\
\hline
\end{tabular}

${ }^{\mathrm{z}}$ LS medium containing $5.0 \mathrm{mgl}^{-1} \mathrm{BA}, 1.0 \mathrm{mgl}^{-1} \mathrm{IAA}$ and $30 \mathrm{gl}^{-1}$ sucrose

${ }^{\mathrm{y}}$ Duncan's multiple range test $(P \leq 0.05)$

$5.0 \mathrm{mgl}^{-1} \mathrm{BA}$ was suitable for shoot proliferation from young shoots (Table 1). The shoot proliferation responses were significantly influenced by the type and concentrations of cytokinin. BA as cytokinins is used widely for multiplication of many ornamental plants because of its high activity for shoot proliferation (Takayama and Misawa 1982; Dewir et al. 2006). In the present study, not only BA but also low concentrations of TDZ were effective for shoot proliferation. TDZ, a synthetic cytokinin was used effectively in the induction of organogenesis (Casanova et al. 2004) and embryogenesis (Visser et al. 1992). Recently, TDZ is used universally even in micropropagation of ornamental plants (Escobar et al. 2008; Jo et al. 2008). To stimulate shoot proliferation more, BA, combined with IAA, was supplemented in the medium. More shoot proliferation response was obtained on LS medium containing $3.0 \mathrm{mgl}^{-1} \mathrm{BA}$ and $0.1 \sim 0.5$ $\mathrm{mgl}^{-1}$ IAA, and $5.0 \mathrm{mgl}^{-1} \mathrm{BA}$ and $0.5 \sim 1.0 \mathrm{mgl}^{-1}$ IAA. Fresh weight per explant increased significantly on LS medium with $5.0 \mathrm{mgl}^{-1} \mathrm{BA}$ and $0.5 \sim 1.0 \mathrm{mgl}^{-1}$ IAA. The best shoot proliferation was achieved on LS medium containing $5.0 \mathrm{mgl}^{-1} \mathrm{BA}$ and $1.0 \mathrm{mgl}^{-1}$ IAA (Table 2). Combined effect of cytokinin and auxin for shoot proliferation depends on species. Generally, addition of cytokinin and auxin together enhanced shoot multiplication in many species (Kusey et al. 1980; Takayama and Misawa 1982; Maesato et al. 1994), but not in some species (Thao et al. 2003; Jo et al. 2008). This might be due to the interaction of auxin with cytokinin during morphogenic events as reported by Eklof et al. (1997) and Sato and Mori (2001). Different gelling substrates were used for shoot proliferation. When shoots were cultured in liquid LS medium, number of shoots and fresh weight per explant increased significantly. The best shoot proliferation and fresh weight increase were achieved on liquid LS medium containing $5.0 \mathrm{mgl}^{-1}$ BA and $1.0 \mathrm{mgl}^{-1}$ IAA with 6.9 shoots and more than $4,000 \mathrm{mg}$ in fresh weight (Table 3). This result can be attributed to the characteristics of water hyacinth as aquatic plant which favors in water (Zimmels et al. 2006; We et al. 2008). Increasing fresh weight would mean increasing biomass. When water hyacinth will be 
Table 4 Effects of salt concentration on shoot proliferation and growth of water hyacinth after 4 weeks in culture ${ }^{\mathrm{z}}$

\begin{tabular}{cccccc}
\hline $\begin{array}{c}\text { Salt } \\
\text { concentration }\end{array}$ & $\begin{array}{c}\text { No. of shoots } \\
\text { /explant }\end{array}$ & $\begin{array}{c}\text { Shoot length } \\
(\mathrm{cm})\end{array}$ & $\begin{array}{c}\text { No. of roots } \\
\text { /explant }\end{array}$ & $\begin{array}{c}\text { Root length } \\
(\mathrm{cm})\end{array}$ & $\begin{array}{c}\text { FW (mg) } \\
\text { /explant }\end{array}$ \\
\hline $2 \mathrm{x}$ & $7.3 \mathrm{a}^{\mathrm{y}}$ & $2.5 \mathrm{a}$ & $5.6 \mathrm{a}$ & $0.6 \mathrm{a}$ & $5,539 \mathrm{a}$ \\
$1 \mathrm{x}$ & $4.3 \mathrm{~b}$ & $2.6 \mathrm{a}$ & $7.4 \mathrm{a}$ & $0.6 \mathrm{a}$ & $3,244 \mathrm{~b}$ \\
$1 / 2 \mathrm{x}$ & $4.6 \mathrm{~b}$ & $2.0 \mathrm{~b}$ & $5.5 \mathrm{a}$ & $0.5 \mathrm{a}$ & $2,782 \mathrm{~b}$ \\
\hline
\end{tabular}

${ }^{\mathrm{z}} \mathrm{LS}$ medium containing $5.0 \mathrm{mgl}^{-1} \mathrm{BA}, 1.0 \mathrm{mgl}^{-1} \mathrm{IAA}$ and $30 \mathrm{gl}^{-1}$ sucrose

${ }^{y}$ Duncan's multiple range test $(P \leq 0.05)$

Table 5 Effects of sucrose concentration on shoot proliferation and growth of water hyacinth after 4 weeks in culture ${ }^{z}$

\begin{tabular}{cccccc}
\hline $\begin{array}{c}\text { Sucrose } \\
\left(\mathrm{gl}^{-1}\right)\end{array}$ & $\begin{array}{c}\text { No. of shoots } \\
\text { /explant }\end{array}$ & $\begin{array}{c}\text { Shoot length } \\
(\mathrm{cm})\end{array}$ & $\begin{array}{c}\text { No. of roots } \\
\text { /explant }\end{array}$ & $\begin{array}{c}\text { Root length } \\
(\mathrm{cm})\end{array}$ & $\begin{array}{c}\text { FW (mg) } \\
\text { /explant }\end{array}$ \\
\hline 30 & $5.2 \mathrm{~b}^{\mathrm{y}}$ & $3.3 \mathrm{a}$ & $3.7 \mathrm{a}$ & $0.9 \mathrm{a}$ & $2,995 \mathrm{~b}$ \\
50 & $8.7 \mathrm{a}$ & $2.6 \mathrm{ab}$ & $4.1 \mathrm{a}$ & $0.7 \mathrm{a}$ & $5,979 \mathrm{a}$ \\
70 & $4.1 \mathrm{c}$ & $2.5 \mathrm{~b}$ & $4.7 \mathrm{a}$ & $0.8 \mathrm{a}$ & $2,943 \mathrm{~b}$ \\
90 & $2.8 \mathrm{~d}$ & $2.1 \mathrm{~b}$ & $3.8 \mathrm{a}$ & $0.8 \mathrm{a}$ & $2,519 \mathrm{~b}$ \\
\hline
\end{tabular}

${ }^{\mathrm{z}} \mathrm{LS}$ medium containing $5.0 \mathrm{mgl}^{-1} \mathrm{BA}, 1.0 \mathrm{mgl}^{-1} \mathrm{IAA}$

${ }^{\text {y }}$ Duncan's multiple range test $(P \leq 0.05)$

used as cost-effective phytoremediation or biofuel plant, this culture condition will be very useful in providing the required raw materials. Moreover, noteworthy results were also observed in using plant agar which had almost doubled the root number and length though the fresh weight was just half. In addition, removal of nitrate, soluble phosphorous (Reddy et al. 1982; Reddy et al. 1983), and heavy metals (Wu et al. 2008) is highly related to the root system. For example, water hyacinth can remove $81 \%$ of arsenic through its fibrous roots (Quayum 2007). With in vitro propagation, suitable culture conditions can be selected. Different concentrations of LS medium salt $(1 / 2,1,2 \mathrm{x})$ and sucrose $\left(30 \sim 90 \mathrm{gl}^{-1}\right)$ were supplemented in the medium to stimulate shoot proliferation. Of the different concentrations of LS salt tested, addition of double strength of LS medium provided the highest shoot proliferation with 7.3 shoots, and fresh weight with $5,539 \mathrm{mg}$ per explant (Table 4). While in the experiment on sucrose concentration, the best shoot proliferation was observed in LS medium containing $50 \mathrm{gl}^{-1}$ sucrose with 8.7 shoots and 5,979 mg per explant in fresh weight (Table 5). The concentration of salt and sucrose in culture medium depends on species, and culture steps and methods. Generally $1 / 2$ to full concentration of salt were used and $30 \mathrm{gl}^{-1}$ sucrose was added to culture medium for shoot proliferation (Faisal et al. 2006). In a procedure for rooting of shoots, reduced concentration of medium salt and sucrose were used (Khan et al. 1999; Singh et al. 2008) However, in bulbous plants, high concentration of culture medium salt and sucrose was oftenly applied to produce more shoots and increase

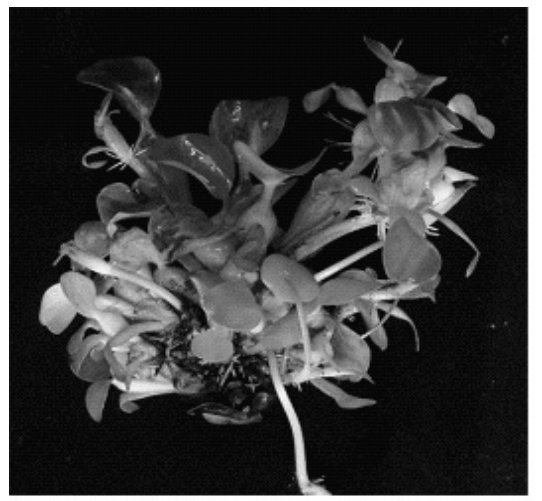

Fig. 1 In vitro proliferated plantlet of water hyacinth (E. crassipes) on double strength LS liquid medium containing $5.0 \mathrm{mgl}^{-1} \mathrm{BA}$, $1.0 \mathrm{mgl}^{-1}$ IAA and $50 \mathrm{gl}^{-1}$ sucrose

bulblet growth (Takayama and Misawa 1983; Bonnier and Van Tuyl 1997; Hu et al. 2006; Joshi and Dhar 2009). In this study, shoot number and fresh weight per explant had increased significantly on medium containing double strength of LS salt and $50 \mathrm{gl}^{-1}$ sucrose. These results can be attributed to the rapid growth of water hyacinth demonstrated by biomass increase (Polprasert et al. 1994) and fast absorption ability of nutrients in nutrient-enriched water ( $\mathrm{Li}$ et al. 2000). Thus, the optimal level for shoot proliferation and biomass increase of water hyacinth was attained with the application of the double strength of LS liquid medium containing $5.0 \mathrm{mgl}^{-1} \mathrm{BA}, 1.0 \mathrm{mgl}^{-1} \mathrm{IAA}$ and $50 \mathrm{gl}^{-1}$ sucrose (Fig. 1). Considering the potential of water hyacinth as ornamental and phytoremediation plants, in vitro micropopagation can be an effective and efficient means to provide 
adequate supply of water hyacinth for the anticipated increase in demandin all season.

\section{Acknowledgement}

This work was supported by a grant from the National Academy of Agricultural Science (project no. PJ006776).

\section{References}

Bhattacharya A, Kumar P (2010) Water hyacinth as a potential biofuel crop. EJEAFChe 9 (1):112-122

Bonnier FJM, Van Tuyl JM (1997) Long term in vitro storage of lily; Effect of temperature and concentration of nutrient and sucrose. Plant cell Tiss Org Cult 9:81-87

Casanova E, Valdes AE, Fernandez B, Moysset L, Trillas MI (2004) Levels and immunolocalization of endogenous cytokinins in thidiazuron-induced shoot organogenesis in carnation. J. Plant Physiol. 161:95-104

Dewir YH, Chakrabarthy D, Hahn EJ, Paek KY (2006) A simple method for mass propagation of Spathiphyllum cannifolium using an airlift bioreactor. In Vitro Cell. Dev Biol Plant 42:291-297

Duncan, DB (1955) Multiple range and multiple F test. Biometrics $11: 1-42$

Eklof S, Astot C, Blackwell J, Moritz T, Olsson O, Sandberg G (1997) Auxin-cytokinin interactions in wild-type and transgenic tobacco. Plant Cell Physiol 38:225-235

Escobar LH, Jordan M, Olate E, Barrales L, Gebauer M (2008) Direct and indirect in vitro organogensis of Leucocoryne purpurea (Alliaceae) a chilean ornamental geophyte. Propagation of Ornamental Plants 8:59-64

Faisal M, Siddique I, Anis M (2006) In vitro rapid regeneration of plantlets from nodal explants of Mucuna pruriens - a valuable medicinal plant. Ann Appl Biol 148:1-6

Gao L, Li B (2006) A potential native natural enemy of invasive aquatic weed-water hyacinth. Biological Invasions 8: 1689-1692

Hu JB, Liu J, Xie CH, Gao XX (2006) Corm induction and multiplication of Amorphophallus albus in vitro. J Hort Sci \& Biotech 81:859-863

Jo UA, Murthy HN, Hahn EJ, Paek KY (2008) Micropropagation of Alocasia amazonica using semi-solid and liquid cultures. In Vitro Cell Dev Biol Plant 44:26-32

Joshi SK, Dhar U (2009) In vitro propagation from axenic explants of Lilium oxypetalum (D. Don) Baker, an endemic bulbous plant of high altitude Himalaya. Acta Physiol Plant 31:833-838

Keskinkan O, Goksu MZL, Yuceer A, Basibuyuk M, Forster CF (2003) Heavy metal adsorption characteristics of a submerged aquatic plant (Myriophyllum spicatum). Process Biochem. 39:179-183
Khan PSSV, Hausman JF, Rao KR (1999) Effect of agar, MS medium strength, sucrose and polyamines on in vitro rooting of Syzygium alternifolium. Biologia Plantarum 42:333-340

Kusey WE, Hammer PA, Weiler TC (1980) In vitro propagation of Gypsophila paniculata L. 'Bristol Fairy'. HortScience 15:600-601

Li XZ, Hao X, Zhu DY (2000) A modified aeration process for promoting nutrient removal using water hyacinth to treat sewage. Environmental Technology 21:525-534

Linsmaire EM, Skoog F (1965) Organic growth factor requirements of tobacco tissue culture. Physiol Plant 18:100-127

Lu X, Kruatrachue M, Pokethitiyookb P, Homyokb K (2004) Removal of Cadmium and Zinc by Water Hyacinth, Eichhornia crassipes. Science Asia 30:93-103

Maesato K, Sharada K, Fukui H, Hara T, Sarma KS (1994) In vitro bulblet regulation from bulbscale explants of Lilium japonicum Thunb. Effect of plant growth regulators and culture environment. J Hort Sci 69:289-297

Mishima D, Tateda M, Ike M, Fujita M (2006) Comparative study on chemical pre-treatments to accelerate enzymatic hydrolysis of aquatic macrophyte biomass used in water purification processes. Bioresource Technology 97:21662172

Quayum SL (2007) Effect of water hyacinth root extract on arsenic level in different organs of arsenic-treated rat. Bangladesh J Pharmacol 2:73-80

Reddy KR, Campell KL, Graetz DA, Portier KM (1982) Use of biological filters for treating agricultural drainage effluents. J. Environ. Qual. 11:591-595

Reddy, KR (1983) Fate of nitrogen and phosphorus in a wastewater retention reservoir containing aquatic macrophytes. J. Environ. Qual. 12;137-141

Reddy, KR, DeBusk, WF (1985) Nutrient removal potential of selected aquatic macrophytes. J. Environ. Qual. 14: 459-462

Polprasert C, Kongsricharoern N, Kanjanaprapin W (1994) Production of feed and fertilizer from water hyacinth plants in the tropics. Waste Manage Res 12:3-11

Roy S, Hanninen O (1994) Pentachlorophenol: uptake/elimination kinetics and metabolism in an aquatic plant, Eichhornia crassipes. Environ Toxic Chem 13:763-773

Sato SS, Mori H (2001) Control in outgrowth and dormancy in auxillary buds. Plant Physiol. 127:1405-1413

Singh A, Reddy MP, Patolia JS (2008) An improved protocol for micropropagation of elite genotypes of Simmondsia chinensis (Link) Schneider. Biologia Plantarum 52: 538-542

Takayama S, Misawa M (1982) Regulation of organ formation by cytokinin and auxin in Lilium bulbscales grown in vitro. Plant Cell Physiol 23:67-74

Takayama S, Misawa M (1983) A scheme for mass propagation of Lilium in vitro. Sci Hort 18:353-362

Thao NTP, Miyajima I, Ureshino K, Ozaki Y, Okubo H (2003) 
Micropropagation of ornamental Alocasia. J Fac Agr Kyushu Univ 47:277-282

Visser C, Quraeshi JA, Gill R, Saxena PK (1992) Morphoregulatory role of thidiazuron, substitution of auxin and cytokinin requirement for the induction of somatic embryogenesis in geranium hypocotyl cultures. Plant Physiol. 99:1704-1707
Wu JS, Ho TC, Chien HC, Wu YJ, Lin SM, Juang RH ( 2008) Characterization of the high molecular weight Cd-binding complex in water hyacinth (Eichhornia crassipes) when exposed to Cd. J Agric Food Chem 56:5806-5812

Zimmels Y, Kirzhner F, Malkovskaja A (2006) Application of Eichhornia crassipes and Pistia stratiotes for treatment of urban sewage in Israel. J Environmental Management $81: 420-428$ 